\title{
THE ROLE OF BOUND CHLORINE IN THE BRIGHTNESS REVERSION OF BLEACHED HARDWOOD KRAFT PULP
}

\author{
Kátia Maria Morais Eiras \\ Suzano Celulose e Papel, BR 101, km 945, 45930-000 Mucuri - BA, Brasil \\ Jorge Luiz Colodette* e Vanessa Lopes Silva \\ Departamento de Engenharia Florestal, Universidade Federal de Viçosa, Av. PH Rolfs, s/n, 36570-000 Viçosa - MG, Brasil
}

Recebido em 26/11/07; aceito em 1/8/08; publicado na web em 18/12/08

\begin{abstract}
Our previous paper showed fragmentary evidence that pulp brightness reversion may be negatively affected by its organically bound chlorine (OX) content. A thorough investigation on eucalyptus kraft pulp led to the conclusion that OX increases reversion of certain pulps but this trend is not universal. Alkaline bleaching stages decrease reversion regardless of pulp OX content. Pulps bleached with high temperature chlorine dioxide revert less than those bleached with conventional chlorine dioxide in sequences ending with a chlorine dioxide stage but similarly in sequences ending with a final peroxide stage. The use of secondary condensate for pulp washing decreases reversion.
\end{abstract}

Keywords: eucalyptus; OX; brightness reversion.

\section{INTRODUCTION}

The mechanisms of brightness reversion are fairly complex and involve a great number of simultaneous reactions. Cellulose is a polyalcohol that can be oxidized during pulp bleaching giving rise to carbonyl and carboxyl groups. ${ }^{1}$ The oxidations lead to reduction of cellulose molecular weight through autocatalytic reactions ${ }^{2}$ and new water-insoluble aromatic structures are formed ${ }^{3}$ from cellulose chain. All these phenomena may contribute to pulp brightness reversion.

A study of the stage-by-stage brightness reversion profile of various bleaching sequences for eucalyptus kraft pulps indicated that a final peroxide bleaching stage improves pulp brightness stability regardless of the sequence. ${ }^{4}$ This fact has been recognized by other researchers ${ }^{5-7}$ and attributed to peroxide oxidation of pulp carbonyl groups $^{5,6}$ and to alkali-induced dissolution of colored substances. ${ }^{7}$ Wood type has also been cited as a source of pulp brightness instability. ${ }^{7-9}$

Pulp bleaching stages based on chlorine and oxygen derived chemicals give rise to a number of oxidative species, including radicals such as $\mathrm{Cl} \bullet, \mathrm{ClO} \bullet, \bullet \mathrm{O}_{2}^{-}, \mathrm{HO} \bullet, \mathrm{HO}_{2} \bullet$ and $\mathrm{H}^{\bullet}$ and cations such as $\mathrm{Cl}^{+}, \mathrm{HO}^{+}, \mathrm{O}_{3}^{+}$and $\mathrm{H}^{+} .{ }^{10}$ These species react preferentially with electron-rich aromatic and olefin structures, but might also react with carbohydrate species. ${ }^{10}$ Pulp bleaching to high brightness requires high oxidant doses to guarantee complete removal of pulp lignin and hexenuronic acids, thus causing some pulp oxidation with the highly reactive species aforementioned. ${ }^{11}$ The control of elemental chlorine and hypochlorous acid concentrations during chlorine dioxide bleaching (Equations 1 and 2) is instrumental to maintain efficiency but these species can give rise to radical species. ${ }^{12}$ Side reactions of chlorous acid and elemental chlorine with iron can also generate chlorine radical ${ }^{13-15}$ according to Equations 3-5.

$$
\begin{aligned}
& \mathrm{ClO}_{2}+\text { lignin }+1 / 2 \mathrm{H}_{2} \mathrm{O} \rightarrow 1 / 2 \mathrm{HClO}+1 / 2 \mathrm{HCl}+\text { oxidized lignin } \\
& 1 / 2 \mathrm{HClO}+1 / 2 \mathrm{HCl} \rightarrow 1 / 2 \mathrm{Cl}_{2}+1 / 2 \mathrm{H}_{2} \mathrm{O}
\end{aligned}
$$

*e-mail: colodett@ufv.br

$$
\begin{aligned}
& \mathrm{HClO}_{2}+\mathrm{Fe}^{2+} \rightarrow \mathrm{ClO} \bullet+\mathrm{Fe}^{3+}+\mathrm{OH}^{-} \\
& \mathrm{HClO}_{2}+\mathrm{ClO} \bullet \rightarrow \mathrm{Cl} \bullet+\mathrm{ClO}_{3}^{-}+\mathrm{H}^{+} \\
& \mathrm{Cl}_{2}+\mathrm{Fe}^{2+} \rightarrow \mathrm{Cl} \bullet+\mathrm{Cl}^{-}+\mathrm{Fe}^{3+}
\end{aligned}
$$

It has been suggested ${ }^{16,17}$ that chlorinated extractives formed in the first chlorine stage causes pulp brightness reversion. Purportedly, the hydrochloric acid released from the pulp hydrolyses polysaccharides, thus releasing colored substances. In addition, the reactions of both chlorine and chlorine dioxide with carbohydrates have been shown ${ }^{18}$ to increase pulp content of uronic acid in holocellulose preparations, likely via oxidation of carbon atom C-6 under acidic conditions as proposed by Whistler cited by Miyazaki. ${ }^{19}$

It has also been reported that certain quinones formed in the first (D0) and in second (D1) chlorine dioxide bleaching stages may remain in the pulp after bleaching and may be responsible for thermal yellowing. ${ }^{20} \mathrm{~A}$ recent study has indicated an increase in brightness reversion, as measured by increase $b^{*}$ coordinate, when elemental chorine is replaced by chlorine dioxide in the first bleaching stage. ${ }^{21}$ This is further indication that quinones derived from lignin may be involved in brightens reversion reactions.

All the above information tends to indicate that brightness reversion of high brightness pulps originates from oxidation of unbleached pulp components (carbohydrate, lignin, extractives and metals) by chlorine based compounds giving rise to materials that are not fully extracted and washed from the pulp in the bleach plant. Such materials retained in the pulp may include uronic acids, other carbonyl/carboxyl groups, oxidized extractives and metals, quinonoid structures, etc. Except for the metals it is not unlikely that most of these materials are chlorinated. Thus, it is postulated that organically bound chlorine may correlate with reversion of standard and ECF bleached Kraft pulps and any measure aimed at minimizing concentration of chlorine based radicals during bleaching should, in principle, decrease pulp tendency to brightness reversion. ${ }^{22}$

The objective of this study was to determine the effect of organically bound chlorine on hardwood pulp brightness reversion. In the first part of the study samples of pure eucalyptus and mixtures of 
maple, birch and cotton pulps were bleached with the $\mathrm{D}(\mathrm{EP}) \mathrm{D}$ and D(EP)DP sequences and tested under same conditions. In the second part of the study a pure sample of eucalyptus pulp was bleached using 12 different bleaching strategies in order to confirm the preliminary results using a broader database. The strategy included the use of variable amounts of active chlorine (kappa factor), in sequences containing (DC), D0 and $\mathrm{D}_{\mathrm{HT}}$ as first stage, first alkaline extraction without (E) and with hydrogen peroxide (EP), third stage (D1) without or with methanol and secondary condensate from black liquor evaporation as additives, forth stage with chlorine dioxide (D2) or peroxide $(\mathrm{P})$ and the use of a second alkali extraction (E) between D1 and D2.

\section{EXPERIMENTAL}

In the first part of the study four oxygen delignified eucalyptus kraft pulps (E1, E2, E3 and E4) and one hardwood mixture comprised of maple, birch and cotton (MBC) were used. Samples E1-E4 were bleached with the sequence D(EP)DD. Sample E3 and E4 were also bleached with the sequence D(EP)DP and are designated in Figure1 as E3P and E4P. The MBC sample was bleached with the sequences $\mathrm{D}(\mathrm{EP}) \mathrm{D}$ and $\mathrm{D}(\mathrm{EP}) \mathrm{DP}$, designated as MBC and MBCP, respectively, in Figure 1. Enough oxidants to reach $90 \%$ ISO brightness were used in all cases. The main bleaching conditions used in each stage were as follows: $\mathrm{D} 0=10 \%$ consistency, $70{ }^{\circ} \mathrm{C}, 120 \mathrm{~min}, \mathrm{pH} \mathrm{3.5}$, kappa factor 0.2 ; (EP): $12 \%$ consistency, $80{ }^{\circ} \mathrm{C}, 120 \mathrm{~min}, \mathrm{pH} 10.4,0.1 \%$ $\mathrm{MgSO}_{4} .7 \mathrm{H}_{2} \mathrm{O} ; 0.25 \% \mathrm{H}_{2} \mathrm{O}_{2}$; D1: $10 \%$ consistency, $70{ }^{\circ} \mathrm{C}, 120 \mathrm{~min}$, pH 3-4, 1-2\% $\mathrm{ClO}_{2}$; P: $10 \%$ consistency, $70{ }^{\circ} \mathrm{C}, 120 \mathrm{~min}, \mathrm{pH} 10-11$, $0.25 \% \mathrm{H}_{2} \mathrm{O}_{2}$. Bleached pulp hand sheets were prepared according to Tappi procedure, dried and sealed in thick-walled plastic bags in a testing laboratory held at $23{ }^{\circ} \mathrm{C}$ and $50 \% \mathrm{RH}$. The plastic bags were then submerged in a $90{ }^{\circ} \mathrm{C}$ water-bath for $4 \mathrm{~h}$. The brightness was measured before and after the heat test using an Elrepho photometer. Pulp organically bound chlorine content was determined by neutron activation analysis (NAA). ${ }^{23}$

In the second part of the study, an oxygen delignified Eucalyptus urograndis kraft pulp of kappa number 10.5, $37.6 \mathrm{mPa}$.s viscosity,

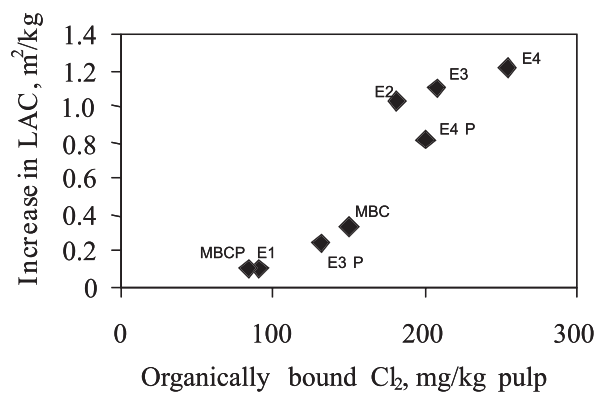

Figure 1. Increase in light absorption coefficient of hardwood pulps during reversion versus amount of bound chlorine remained in pulp after bleaching
$53.6 \%$ ISO brightness and $51 \mathrm{mmol} / \mathrm{kg}$ hexenuronic acids (HexA's) content was used. Chlorine dioxide (10\%)/chlorine (90\%) (DC), chorine dioxide (D), peroxide reinforced alkali extraction (EP), alkali extraction (E) and hydrogen peroxide (P) bleaching stages were performed in polyethylene bags. Hot chlorine dioxide (DHT) was performed in a teflon-lined mixer/reactor (Quantum Technologies, model Mark V). The desired charges of chemicals were added to the pulp and the mixtures heated to the desired temperature in a microwave oven. The samples were then placed in a heating bath for the desired reaction time. All bleaching stages were carried out in duplicate under the general bleaching conditions shown in Table 1. Inter-stage washings simulated a vacuum filter operating at a dilution factor of two (inlet and outlet consistencies of $1.5 \%$ and $10 \%$, respectively). After bleaching, pulp was diluted to $0.3 \%$ consistency, $\mathrm{pH}$ was adjusted to 5.5-6 with $\mathrm{SO}_{2} / \mathrm{H}_{2} \mathrm{SO}_{4}$ or $\mathrm{SO}_{2} / \mathrm{NaOH}$, and five sheets were formed and dried for $12 \mathrm{~h}$ to $9-10 \%$ humidity in an environmentally controlled room $(50 \pm 2 \%$ relative humidity and 23 $\left.\pm 1{ }^{\circ} \mathrm{C}\right)$. Brightness reversion tests were performed in conformity with Tappi UM 200 method $\left(4 \mathrm{~h}, 105 \pm 3{ }^{\circ} \mathrm{C}, 0 \%\right.$ relative humidity). Reversion results were expressed as post color number (PCN) in conformity with Tappi standard TIS 017-10. Pulp hexenuronic acids and organically bound chlorine (OX) were measured according to the $\mathrm{HUT}^{24}$ and $\mathrm{PTS}^{25}$ procedures, respectively.

\section{RESULTS AND DISCUSSION}

\section{Part I}

The results presented in Figure 1 shows reasonable correlation between pulp organically bound chlorine and brightness reversion as measured by the increase in light absorption coefficient (LAC). Each point in the curve designates a different sample bleached with the sequence $\mathrm{D}(\mathrm{EP}) \mathrm{D}$ or $\mathrm{D}(\mathrm{EP}) \mathrm{DP}$. Although many other factors may be involved in reversion as previously discussed, ${ }^{4}$ the data in Figure 1 suggests something new and worth investigating deeply. A possible explanation for this correlation is that thermal fission of $\mathrm{C}-\mathrm{Cl}$ bonds may occur during heating of the pulp (Equation 6), giving rise to highly reactive free radicals. The bond dissociation energy (BDE) for most $\mathrm{C}-\mathrm{Cl}$ bonds is less than for the corresponding $\mathrm{C}-\mathrm{H}$ or $\mathrm{C}-\mathrm{OH}$ bonds. Thus, the formation of carbon-centered $\mathrm{Cl} \bullet$ free radicals are very likely. The brightening effect of $\mathrm{Cl} \bullet$ atoms would be expected to be minimal and actually, could generate more carbon-centered free radicals, Equation $7 .^{25}$

$$
\begin{aligned}
& -\mathrm{C}-\mathrm{Cl} \stackrel{\Delta}{\rightarrow} \mathrm{C} \bullet+\mathrm{Cl} \bullet \\
& -\mathrm{C}-\mathrm{H}+\mathrm{Cl} \bullet \rightarrow \mathrm{C} \bullet+\mathrm{HCl}
\end{aligned}
$$

Therefore, the bleaching chemistry can affect brightness reversion substantially. For example, terminating a bleaching sequence with chlorine dioxide stages (D1 and D2) increases pulp organically

\begin{tabular}{|c|c|c|c|c|c|c|c|c|c|}
\hline \multirow{2}{*}{$\begin{array}{l}\text { Bleaching Stage } \\
\text { Conditions }\end{array}$} & \multicolumn{3}{|c|}{ First Stage } & \multicolumn{2}{|c|}{ Second Stage } & \multirow{2}{*}{$\begin{array}{c}\text { Third Stage } \\
\text { D }\end{array}$} & \multirow{2}{*}{$\begin{array}{c}\text { Fourth Stage } \\
\text { E } \\
\end{array}$} & \multicolumn{2}{|c|}{ Forth or Fifth Stage } \\
\hline & $\mathrm{D}$ & $\mathrm{D}_{\mathrm{HT}}$ & (DC) & E & (EP) & & & $\mathrm{D}$ & $\mathrm{P}$ \\
\hline Consistency, $\%$ & 10 & 10 & 4 & 10 & 10 & 10 & 10 & 10 & 10 \\
\hline Temperature, ${ }^{\circ} \mathrm{C}$ & 70 & 90 & 50 & 80 & 90 & 70 & 80 & 70 & 80 \\
\hline Time, min & 30 & 120 & 30 & 120 & 180 & 120 & 60 & 120 & 120 \\
\hline Kappa Factor & $0.15-0.3$ & $0.15-0.3$ & $0.15-0.3$ & - & - & - & - & - & - \\
\hline $\mathrm{pH}$ & 3.5 & 3.4 & 2.7 & 10.5 & 11.8 & $4-4.5$ & 10.7 & 5.5 & 11.5 \\
\hline
\end{tabular}

Table 1. General bleaching conditions to reach $90.2-93.1 \%$ ISO brightness 
bound chlorine content while extraction and peroxide stages $\left(\mathrm{OH}^{-}\right.$, $\mathrm{OOH}^{-}$) decrease it by nucleophilic displacement. ${ }^{26}$ Proper washing tends to remove bound chlorine from the pulp, thus minimizing the detrimental effect caused by free radicals derived from chlorine compounds. Although not conclusive, it does appear that more bound $\mathrm{Cl}_{2}$ is generated in eucalyptus pulps.

\section{Part II}

To further confirm the trend observed in Part I whereby brightness reversion seemed to correlate with pulp content of organically bound chlorine, a more thorough evaluation of the problem was undertaken. A unique eucalyptus pulp sample was bleached to full brightness with 18 different sequences, namely: (DC)(EP)DD, (DC) EDD, (DC)(EP)DED, (DC)EDED, D(EP)DD, DEDD, D(EP)DED, DEDED, $\mathrm{D}_{\mathrm{HT}}(\mathrm{EP}) \mathrm{DD}, \mathrm{D}_{\mathrm{HT}} \mathrm{EDD}, \mathrm{D}_{\mathrm{HT}}(\mathrm{EP}) \mathrm{DED}, \mathrm{D}_{\mathrm{HT}} \mathrm{EDED}(\mathrm{DC})$ (EP)DP, (DC)EDP, D(EP)DP, DEDP, $\mathrm{D}_{\mathrm{HT}}(\mathrm{EP}) \mathrm{DP}$ and $\mathrm{D}_{\mathrm{HT}} \mathrm{EDP}$. The $\mathrm{D}(\mathrm{EP}) \mathrm{DD}$ sequence served as reference and was modified in different ways to produce bleached pulps containing a large spectrum of organically bound chlorine (OX) contents. This was possible by over emphasizing the use of elemental chlorine in those sequences containing the (DC) stage and under emphasizing it in the ECF sequences. Bleached pulp final brightness varied in the range of to 90.2-93.1\% despite the fact that total active chlorine consumption varied in the narrow range of $4.75-4.87 \%$ (Table 2). This further illustrates the well-known fact that bleaching efficiency depends upon the arrangement of stages and the type of oxidants used. It is worth noting that organically bound chlorine varied substantially among the various sequences, from 131 to $474 \mathrm{mg} \mathrm{Cl} / \mathrm{kg}$ pulp, despite the nearly similar total active chlorine charges used in the various sequences (Table 2). This large variation is easily explained considering that some sequences were heavily based on elemental chlorine, others on chlorine dioxide and others on hydrogen peroxide. As expected the highest $\mathrm{OX}$ values were seen in sequences based on elemental chlorine and the lowest values in those having more hydrogen peroxide (Figure 2).

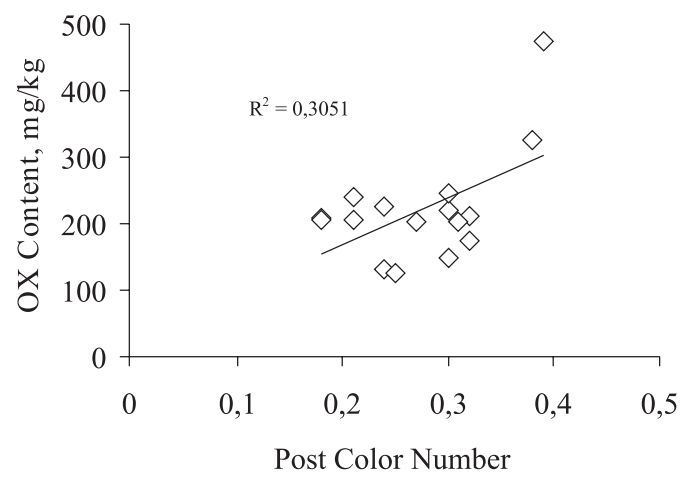

Figure 2. Brighness reversion (PCN) of pulps bleached by various sequences versus amount of bound chlorine remained in pulp

\section{Sequences starting with a (DC)-stage}

Table 2 present results for the sequences (DC)(EP)DD, (DC) (EP)DED, (DC)(EP)DP, (DC)EDD, (DC)EDED and DCEDP. Reversion is expressed as post color number (PCN) and organically bound chlorine as $\mathrm{OX}$ values $(\mathrm{mg} / \mathrm{kg}$ pulp). Other relevant parameters such as doses of chlorine based chemicals used for bleaching and bleached pulp content of hexenuronic acids are also presented. Highest PCN values were verified with the pulps that contained the highest $\mathrm{OX}$ values, indicating a negative effect of organically bound chlorine on pulp brightness stability. It is worth

Table 2. Overall oxidant consumption, brightness, HexA's, OX and brightness reversion (PCN) for pulp bleached with various sequences

\begin{tabular}{|c|c|c|c|c|c|c|c|c|c|}
\hline Sequence & $\begin{array}{l}\text { Kappa } \\
\text { Factor }\end{array}$ & $\mathrm{Cl}_{2}, \%$ & $\begin{array}{c}\mathrm{ClO}_{2} \text { as } \mathrm{Cl}_{2}, \\
\%\end{array}$ & $\mathrm{H}_{2} \mathrm{O}_{2}, \%$ & $\begin{array}{l}\text { Total Active } \\
\mathrm{Cl}_{2}, \%\end{array}$ & $\begin{array}{c}\text { Brightness, } \\
\% \text { ISO }\end{array}$ & $\begin{array}{l}\text { HexA's, } \\
\mathrm{mmol} / \mathrm{kg}^{\mathrm{a}}\end{array}$ & $\begin{array}{c}\mathrm{OX}, \\
\mathrm{mg} / \mathrm{kg}^{\mathrm{b}}\end{array}$ & $\mathrm{PCN}^{\mathrm{c}}$ \\
\hline$(\mathrm{DC})(\mathrm{EP}) \mathrm{DD}$ & 0.15 & 1.41 & 1.26 & 1.0 & 4.76 & 91.2 & 2.8 & 326 & 0.38 \\
\hline$(\mathrm{DC})(\mathrm{EP}) \mathrm{DED}$ & 0.15 & 1.41 & 1.26 & 1.0 & 4.76 & 93.1 & 2.3 & 212 & 0.32 \\
\hline$(\mathrm{DC})(\mathrm{EP}) \mathrm{DP}$ & 0.15 & 1.41 & 1.16 & 1.1 & 4.87 & 91.6 & 2.4 & 205 & 0.21 \\
\hline (DC)EDD & 0.30 & 2.83 & 1.92 & 0 & 4.75 & 91.8 & 2.7 & 474 & 0.39 \\
\hline (DC)EDED & 0.30 & 2.83 & 1.92 & 0 & 4.75 & 91.8 & 2.6 & 221 & 0.30 \\
\hline (DC)EDP & 0.30 & 2.83 & 1.82 & 0.1 & 4.86 & 90.2 & 2.9 & 226 & 0.24 \\
\hline $\mathrm{D}(\mathrm{EP}) \mathrm{DD}$ & 0.15 & 0 & 2.67 & 1.0 & 4.76 & 91.1 & 14.7 & 152 & 0.51 \\
\hline $\mathrm{D}(\mathrm{EP}) \mathrm{DED}$ & 0.15 & 0 & 2.67 & 1.0 & 4.76 & 92.1 & 14.9 & 149 & 0.30 \\
\hline $\mathrm{D}(\mathrm{EP}) \mathrm{DP}$ & 0.15 & 0 & 2.57 & 1.1 & 4.87 & 91.2 & 15.2 & 131 & 0.24 \\
\hline DEDD & 0.30 & 0 & 4.75 & 0 & 4.75 & 91.1 & 4.9 & 202 & 0.31 \\
\hline DEDED & 0.30 & 0 & 4.75 & 0 & 4.75 & 92.3 & 4.7 & 204 & 0.27 \\
\hline DEDP & 0.30 & 0 & 4.65 & 0.1 & 4.86 & 91.2 & 5.4 & 209 & 0.18 \\
\hline $\mathrm{D}_{\mathrm{HT}}(\mathrm{EP}) \mathrm{DD}$ & 0.15 & 0 & 2.67 & 1.0 & 4.76 & 91.0 & 11.8 & 178 & 0.39 \\
\hline $\mathrm{D}_{\mathrm{HT}}(\mathrm{EP}) \mathrm{DED}$ & 0.15 & 0 & 2.67 & 1.0 & 4.76 & 92.2 & 11.1 & 174 & 0.32 \\
\hline $\mathrm{D}_{\mathrm{HT}}(\mathrm{EP}) \mathrm{DP}$ & 0.15 & 0 & 2.57 & 1.1 & 4.87 & 91.3 & 12.5 & 126 & 0.25 \\
\hline $\mathrm{D}_{\mathrm{HT}} \mathrm{EDD}$ & 0.30 & 0 & 4.75 & 0 & 4.75 & 91.2 & 3.2 & 246 & 0.30 \\
\hline $\mathrm{D}_{\mathrm{HT}} \mathrm{EDED}$ & 0.30 & 0 & 4.75 & 0 & 4.75 & 92.9 & 2.9 & 239 & 0.21 \\
\hline $\mathrm{D}_{\mathrm{HT}} \mathrm{EDP}$ & 0.30 & 0 & 4.65 & 0.1 & 4.86 & 91.4 & 3.4 & 207 & 0.18 \\
\hline
\end{tabular}

${ }^{\mathrm{a}}$ hexenuronic acids, ${ }^{\mathrm{b}}$ organically bound chlorine, ${ }^{\mathrm{c}}$ post color number 
noting that sequences having a second alkaline extraction (E2) or a final peroxide stage $(\mathrm{P})$ showed lower $\mathrm{PCN}$ values than the reference, which is in agreement with previous work. ${ }^{4}$ It is apparent that brightness stability improvement caused by these alkaline treatments results from their high effectiveness in removing the organically bound chlorine and other reducing materials existing in the pulp. Apparently, large quantities of organically bound chlorine exists in the pulp originated from the (DC) stage, which are quite soluble in alkali and readily removed in the E2 or P stages. The question that remains is whether organically bound chlorine is simply made soluble in alkali or de-chlorinated via nucleophilic reactions with $\mathrm{HO}^{-}$and/or $\mathrm{HOO}^{-}$species existing in the $\mathrm{E} 2$ and $\mathrm{P}$ stages as recently proposed. ${ }^{5}$ No significant differences were observed in the hexenuronic acid (HexA's) content among the various pulps, which was very low in all cases.

\section{Sequences starting with a D0-stage}

The pulps bleached with the sequences $\mathrm{D}(\mathrm{EP}) \mathrm{DD}, \mathrm{D}(\mathrm{EP}) \mathrm{DED}$ and $\mathrm{D}(\mathrm{EP}) \mathrm{DP}$ present lower values of OX in relation to those bleached with the sequences DEDD, DEDED and DEDP, reflecting the lower use of chlorine dioxide in the former three. In this case, no apparent correlation exists between brightness reversion and organically bound chlorine. The use of a second alkaline extraction or a final $\mathrm{P}$ stage had no significant impact on the amount of pulp organically bound chlorine, indicating that the nature of these compounds produced in the D0 stage differs significantly from those produced in the (DC) stage, which were extracted in large extent by the E2 and final $\mathrm{P}$ stages. It is possible that a large fraction of the OX produced in the (DC) stage is actually derived from the reaction of elemental chlorine with hexenuronic acids (HexA's). Organically bound chlorine derived from HexA's is easily de-chlorinated under neutral $\mathrm{pH}$ and ambient temperature $^{27}$ or slightly acidic conditions at high temperature. ${ }^{28}$ Although the E2 and final P stages had no positive effect on pulp OX content they did decrease brightness reversion, indicating that other factors besides organically bound chlorine affected brightness stability in this case. The content pulp HexA's content was not affected significantly by E2 and final P stages and cannot explain the decrease in reversion caused by these stages. Other possibilities include removal of some form of reducing compounds present in the pulp, which are soluble in alkali, as recently proposed. ${ }^{4}$ Contrary to what was shown for sequences starting up with the (DC) stage, increasing D0 stage kappa factor improved pulp brightness stability quite significantly. This result may be explained by more efficient removal of pulp hexenuronic acid by chlorine dioxide at the higher kappa factor. When in excess, hexenuronic acids can cause brightness reversion. ${ }^{29}$ However; the results clearly indicate that the negative effect of HexA's on reversion can be easily counteracted by the presence of a second extraction or a final P-stage in the sequence.

\section{Sequences starting with a DHT-stage}

For sequences starting with a $\mathrm{D}_{\mathrm{HT}}$ stage no apparent correlation exists between brightness reversion and organically bound chlorine. The trends here are similar to those observed for sequences starting with the D0 stage. The only difference worth noting is that at the low kappa factor of 0.15 the pulp bleached by the $\mathrm{D}_{\mathrm{HT}}(\mathrm{EP}) \mathrm{DD}$ sequence showed significantly lower reversion than that bleached with the $\mathrm{D}(\mathrm{EP}) \mathrm{DD}$. This can be explained considering the significant differences in HexA's content between the two pulps, 14.7 for the former and $11.8 \mathrm{mmol} / \mathrm{kg}$ for the latter. When these two pulps were treated either with an E2 or final P stage the reversion levels became similar. For the higher kappa factor no reversion differences were observed between the sequences starting with $\mathrm{D} 0$ or $\mathrm{D}_{\mathrm{HT}}$ stages. Therefore, it can be stated that at sufficiently high kappa factor (e.g. 0.30) there is no difference between $\mathrm{D} 0$ and $\mathrm{D}_{\mathrm{HT}}$ as far as pulp brightness stability is concerned. This has been shown by other workers. ${ }^{30}$

\section{Effect of methanol and clean condensate application in D1 stage}

Preliminary results obtained in our laboratory with a different oxygen delignified eucalyptus kraft pulp sample (kappa 9.9, viscosity $27.5 \mathrm{mPa}$.s, brightness $38.2 \%$ ISO) have indicated that application of secondary condensate from black liquor evaporation in the $\mathrm{D} 0$ and $\mathrm{D}_{\mathrm{HT}}$ stages of the $\mathrm{D}(\mathrm{EPO}) \mathrm{DP}$ and $\mathrm{D}_{\mathrm{HT}}(\mathrm{EPO}) \mathrm{DP}$ sequences, respectively, decreases brightness reversion substantially (Table 3 ). The benefits of using condensate may be related to its composition, estimated in $\mathrm{kg}$ oxygen chemical demand, that includes methanol $(0.3 \mathrm{~kg} \mathrm{COD} / \mathrm{kg})$, ethanol (2.1 kg COD/kg), formic acid $(0.3 \mathrm{~kg} \mathrm{COD} / \mathrm{kg})$, acetic acid $(1.1 \mathrm{~kg} \mathrm{COD} / \mathrm{kg})$, propionic acid $(1.7 \mathrm{~kg} \mathrm{COD} / \mathrm{kg})$ and acetone $(2.3 \mathrm{~kg}$ $\mathrm{COD} / \mathrm{kg}$ ), besides some reduced forms of sulfur such as $\mathrm{H}_{2} \mathrm{~S}$, methyl mercaptan, dimethyl sulfide and dimethyl disulfide. ${ }^{31}$ Since methanol is the most prominent chemical present in clean condensate, it was also evaluated in a separate experiment for the sequence D(EP)DD. Both methanol and clean condensate where added to the D1 stage rather than in the $\mathrm{D} 0$ or $\mathrm{D}_{\mathrm{HT}}$ as done previously. The results indicate that both clean condensate and methanol decrease brightness reversion (Table 4). However, the positive impact of the condensate was much lower in this case than previously found (Table 3). It is possible that most of the harmful species that causes reversion are generated in the first bleaching stage (D0 or $\mathrm{D}_{\mathrm{HT}}$ ) rather than in the D1 stage, or that the benefits of using condensate are greater in sequences ending with a final P stage (Table 3). This issue remains to be investigated in further studies that we are conducting. The mechanism by which both clean condensate and methanol minimize reversion is likely to capture of free radicals $(\mathrm{Cl} \bullet$ or $\mathrm{HO} \bullet)$ that promote formation of carbonyl groups as well as organically bound chlorine in the pulp. Both methanol and ethanol are known to function as free radical scavengers for hydroxyl radicals.

Table 3. Overall oxidant consumption, brightness, HexA', and brightness reversion (PCN) for pulp bleached with various sequences, with and without condensate dosed to D0 and $\mathrm{D}_{\mathrm{HT}}$

\begin{tabular}{lccccccc}
\hline Sequence & $\begin{array}{c}\text { Kappa } \\
\text { Factor }\end{array}$ & $\begin{array}{c}\mathrm{ClO}_{2} \mathrm{as} \mathrm{Cl}_{2}, \\
\%\end{array}$ & $\begin{array}{c}\mathrm{H}_{2} \mathrm{O}_{2}, \\
\%\end{array}$ & $\begin{array}{c}\text { Total Active } \\
\mathrm{Cl}_{2}, \%\end{array}$ & $\begin{array}{c}\text { Brightness, } \\
\% \text { ISO }\end{array}$ & $\begin{array}{c}\mathrm{HexA}^{\prime} \mathrm{s}, \\
\mathrm{mmol}^{2} \mathrm{~kg}^{\mathrm{a}}\end{array}$ \\
\hline $\mathrm{D}(\mathrm{EP}) \mathrm{DP}$ & 0.26 & 4.5 & 0.5 & 5.54 & 90.8 & 4.6 & 0.28 \\
$\mathrm{Dc}(\mathrm{EP}) \mathrm{PP}^{\mathrm{c}}$ & 0.26 & 4.5 & 0.5 & 5.54 & 90.6 & 4.7 & 0.15 \\
$\mathrm{D}_{\mathrm{HT}}(\mathrm{EP}) \mathrm{DP}$ & 0.26 & 4.5 & 0.5 & 5.54 & 90.9 & 2.1 & 0.26 \\
$\mathrm{D}_{\mathrm{HT}} \mathrm{c}(\mathrm{EP}) \mathrm{DP}$ & 0.26 & 4.5 & 0.5 & 5.54 & 90.7 & 2.6 \\
\hline
\end{tabular}

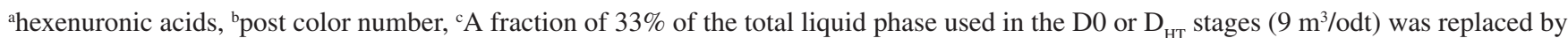
secondary condensate from black liquor evaporation. 
Table 4. Overall oxidant consumption, brightness, HexA's, OX and brightness reversion (PCN) for pulp bleached with various sequences, with methanol and condensate dosed in D1

\begin{tabular}{|c|c|c|c|c|c|c|c|c|}
\hline Sequence & $\begin{array}{l}\text { Kappa } \\
\text { Factor }\end{array}$ & $\begin{array}{c}\mathrm{ClO}_{2} \text { as } \mathrm{Cl}_{2} \\
\%\end{array}$ & $\begin{array}{c}\mathrm{H} 2 \mathrm{O}, \\
\%\end{array}$ & $\begin{array}{c}\text { Total Active } \\
\mathrm{Cl}_{2}, \%\end{array}$ & $\begin{array}{c}\text { Brightness, } \\
\text { \% ISO }\end{array}$ & $\begin{array}{l}\text { HexA's, } \\
\mathrm{mmol} / \mathrm{kg}^{\mathrm{a}}\end{array}$ & $\begin{array}{c}\mathrm{OX} \\
\mathrm{mg} / \mathrm{kg}^{\mathrm{b}}\end{array}$ & $\mathrm{PCN}^{c}$ \\
\hline $\mathrm{D}(\mathrm{EP}) \mathrm{DD}$ & 0.15 & 2.67 & 1.0 & 4.76 & 91.1 & 14.7 & 152 & 0.51 \\
\hline $\mathrm{D}(\mathrm{EP}) \mathrm{DmD} \mathrm{d}^{\mathrm{d}}$ & 0.15 & 2.67 & 1.0 & 4.76 & 91.1 & 14.4 & 149 & 0.38 \\
\hline $\mathrm{D}(\mathrm{EP}) \mathrm{DcD}^{\mathrm{e}}$ & 0.15 & 2.57 & 1.1 & 4.87 & 91.7 & 14.8 & 131 & 0.32 \\
\hline DEDD & 0.30 & 4.75 & 0 & 4.75 & 91.1 & 4.90 & 202 & 0.31 \\
\hline $\mathrm{DEDmD}^{\mathrm{d}}$ & 0.30 & 4.75 & 0 & 4.75 & 90.9 & 4.70 & 204 & 0.25 \\
\hline $\mathrm{DEDcD}^{\mathrm{e}}$ & 0.30 & 4.65 & 0.1 & 4.86 & 91.1 & 5.40 & 209 & 0.24 \\
\hline
\end{tabular}

${ }^{\mathrm{a} h e x e n u r o n i c}$ acids, ${ }^{\mathrm{b}}$ organically bound chlorine, ${ }^{\mathrm{c}}$ post color number, ${ }^{\mathrm{d}} \mathrm{Dm}$ : $10 \%$ (on pulp wt.) of methanol was added to the D1 stage, ${ }^{\mathrm{e}} \mathrm{Dc}$ : A fraction of $33 \%$ of the total liquid fraction used in the D1 stage $\left(9 \mathrm{~m}^{3} / \mathrm{odt}\right)$ was replaced by secondary condensate from black liquor evaporation.

\section{CONCLUSIONS}

Organically bound chlorine increases brightness reversion of certain bleached pulps but this trend is not universal.

Pulps bleached with sequences containing a second alkaline extraction or final peroxide stages are less prone to reversion regardless of their content of bound chlorine.

Pulp bleached with a hot chlorine dioxide stage $\left(\mathrm{D}_{\mathrm{HT}}\right)$ is more stable than that bleached with conventional chlorine dioxide (D0) in sequences ending with a chorine dioxide stage. This effect disappears in sequences ending with a final peroxide stage.

The use of secondary condensate from black liquor evaporation in $\mathrm{D} 0$ or $\mathrm{D}_{\mathrm{HT}}$ stages of the $\mathrm{D}_{\mathrm{HT}}(\mathrm{EP}) \mathrm{DP}$ and $\mathrm{D} 0(\mathrm{EP}) \mathrm{DP}$ sequences decreases reversion substantially, with the benefit being much smaller when the condensate is applied to the D1 stage of the sequences $\mathrm{D}(\mathrm{EP}) \mathrm{DD}$ and DEDD.

\section{REFERENCES}

1. Kochetkov, N. K.; Kudrjashov, L. I.; Chlenov, M. A.; Radiation Chemistry of Carbohydrates, Pergamon Press: Oxford, 1979.

2. Denisov, E. T.; Mitskevich, N. I.; Agabekov, V. E.; Liquid-Phase Oxidation of Oxygen Containing Compounds, Consultants Bureau: New York, 1977.

3. Granström, A.; Eriksson, T.; Gellerstedt, G.; Nord. Pulp Pap. Res. J. 2001, 16, 18.

4. Eiras, K. M. M.; Colodette, J. L.; J. Pulp Pap. Sci. 2005, 31, 1.

5. Lachenal, D.; Nguyen-Thi, N. B.; Proceedings at Tappi Pulping Conference, Atlanta, USA, 1993.

6. Anderson, J. R.; Amini, B. In Pulp Bleaching; Dance, C. W.; Reeve, D. W., eds., Tappi Press: USA, 1996, p.411-442.

7. Foresail, I. In Papermaking Science and Technology Series; Guilloches J.; Paulapuro, H., eds., Tappi Press: USA, 2000, p. 277-350.

8. Colodette, J. L.; Eiras, K. M. M.; Oliveira, R.; Ventorim, G.; Appita J. 2004, 11, 481.

9. Gomide, J. L.; Colodette, J. L.; Oliveira, R. C.; Silva, C. M.; Rev. Árvore 2005, 29, 129.
10. Gierer, J.; Holzforschung 1990, 44, 387.

11. Tessier, P.; Savoie, M.; Tappi J. 2002, 1, 79.

12. Joncourt, M. J.; Foment, P.; Lachenal, D.; Chirat, C.; Proceedings at CTP $2^{\text {nd }}$ Forum Associate Members, Grenoble, França, 1997.

13. Schmitz, G.; Rooze, H.; Can. J. Chem. 1981, 59, 1177.

14. Schmitz, G.; Rooze, H.; Can. J. Chem. 1984, 62, 2231.

15. Schmitz, G.; Rooze, H.; Can. J. Chem. 1985, 63, 975.

16. Coon, I.; Dillén, S.; Olsson, J-E.; Svensk Papperstidning 1966, 69, 139.

17. Howard, E. J.; Histed, J. A.; Tappi J. 1964, 47, 214.

18. Stewart, C. M.; Smelstorius, J. A.; Chem. Ind. 1968, 618.

19. Miyazaki, K.; Smelstorius, J. A.; Hardwood, B. J.; Stewart, C. M.; Appita J. 1971, 24, 452.

20. Brogdon, B. N.; J. Pulp Pap. Sci. 2001, 27, 364.

21. Tran, A. V.; J. Pulp Pap. Sci. 2002, 28, 115.

22. Costa, M. M.; Colodette, J. L.; Landim, A.; Rev. Árvore. 2006, 30, 129.

23. Stevens, B. J.; Sell, L. O.; Easty, D. B.; The Institute of Paper Chemistry, IPC Technical Paper Series, number 323, Appleton: Wisconsin, 1989.

24. Vuorinen, T.; Teleman, A.; Fagerstrom, P.; Buchert, J.; Tenkanen, M.; Proceedings at Internacional Pulp Bleaching Conference. Washington, USA, 1996.

25. PTS Method PTS-RH 012/90; Determination of the total halogenated organics Papiertechnische Stiftung, HeBstrabe, Munchen, 1990.

26. Eiras, K. M. M.; Colodette, J. L.; Francis, R. C.; Espra Res. Rep. 2004, 121,35 .

27. Bjorklund, M.; Germgard, U.; Basta, J.; Tappi J. 2004, 3 , 7.

28. Ventorim, G.; Colodette, J. L.; Eiras, K. M. M.; Nord. Pulp Pap. Res. J. 2005, 20,7 .

29. Buchert, J.; Bergnor, E.; Lindblad, G.; Viikari, L.; Ek, M.; Tappi J. 1997, $80,165$.

30. Costa, M. M.; Oliveira, M. J.; Santos, C. A.; Filho, C. L.; Proceedings at Internacional Colloquium on Celulose de Eucalyptus Kraft Pulp, Viçosa, Brazil, 2003.

31. Viirimaa, M.; Sillanpaa, M.; Ala Kaila, K.; Dahl, O.; Proceedings at Internacional Pulp Bleaching Conference, Oregon, USA, 2002. 